\title{
HUBUNGAN SIKAP TENTANG HIPERTENSI DENGAN FREKUENSI KEKAMBUHAN HIPERTENSI PADA PENDERITA HIPERTENSI DI RW 06 KARAH KECAMATAN JAMBANGAN SURABAYA
}

\section{Relationship Attitude of Hypertension with the frequency of recurrence hypertension in the hypertension patient in RW 06 Karah Kecamatan Jambangan Surabaya}

\author{
Nur Ainiyah, Lono Wijayanti \\ Fakultas Keperawatan dan Kebidanan, Universitas Nahdlatul Ulama Surabaya \\ ainiyahannuri@unusa.ac.id
}

\begin{abstract}
ABSTRAK
Kekambuhan pada penderita hipertensi sering terjadi selama hidupnya. Kekambuhan tersebut merupakan dampak dari faktor sikap yang tidak dapat dihindari oleh individu, antara lain ketidak adequatan dalam menghadapi stress, beban kerja yang cukup tinggi., gaya hidup yang tidak sehat, dan konsumsi makanna yng tidak sehat. Prevalensi di kejadian hipertensi di perkotaan $39,9 \% \quad(37,0 \%-45,8 \%)$ dan di pedesaan $44,1 \% \quad(36,2 \%-51,7 \%)$. Kenyataan yang ada di masyarakat menunjukkan tingginya prevalensi penderita hipertensi, dimana dari data di Posyandu Lansia di Karah meningkat tiap bulannya.

Metode dalam penelitian ini adalah deskriptif analitik dengan menggunakan tehnik sampling yaitu accidental sampling sejumlah 24 orang yang menderita hipertensi di RW 06 Kelurahan Karah Kecamatan Jambangan Variabel dalam penelitian ini adalah sikap tentang hipertensi dan frekuensi kekambuhan. Pengumpulan data menggunakan kuesioner. Analisa data yang digunakan uji statististik lambda.

Berdasarkan hasil perhitungan statistik uji (lambda) didapatkan nilai probabilitas (p) sebesar 0.000 lebih kecil dari $\alpha(0.05)$ maka Ho ditolak dan Ha diterima yang menunjukan adanya hubungan yang signifikan antara sikap tentang hipertensi dengan frekwensi kekambuhan pada penderita hipertensi di RW 06 Karah Kecamatan Jambangan Surabaya., selain itu juga didaptkan nilai besarnya korelasi 0.467 yang menunjukkan bahwa kekuatan korelasinya sedang.

Penerapan sikap yang favorable (mendukung) sebagai salah satu alternative cara yang dapat dilakukan oleh penderita hipertensi untuk meminimalkan frekuensi kekambuhan hipertensi, melalui pengaturan dan modifikasi diit pada penderita hipertensi serta perlu adanya penyuluhan tentang hipertensi tersebut yang dilakukan secara berkesinambungan oleh tenaga kesehatan.
\end{abstract}

Kata Kunci : sikap, frekuensi kekambuhan, hipertensi

\begin{abstract}
Recurrence is the impact of attitudinal factors that cannot be avoided by individuals, including inadequacy in dealing with stress, high workloads, unhealthy lifestyles, and unhealthy eating. The prevalence of hypertension in urban areas is $39.9 \%(37.0 \%-45.8 \%)$ and in rural areas $44.1 \%(36.2 \%-51.7 \%)$. The reality in the community shows the high prevalence of hypertensive patients, where data from the Elderly Posyandu in Karah increases every month.
\end{abstract}


The method in this research is analytic descriptive by using a sampling technique that is accidental sampling a number of 24 people suffering from hypertension in the Elderly Posyandu RW 06 Karah Kecamatan Jambangan. Variables in this study were attitudes about hypertension and frequency of recurrence. Data collection using a questionnaire. Data analysis used lambda statistical test.

Based on the results of the calculation of test statistics (lambda), the probability value (p) of 0.000 is smaller than $\alpha(0.05)$, Ho is rejected and $\mathrm{Ha}$ is accepted which shows a significant relationship between attitudes about hypertension and recurrence in hypertensive patients in RW 06 Karah Kecamatan Jambangan Surabaya. In addition, the value of the correlation is 0.467 which indicates that the correlation strength is moderate.

Application of a favorable attitude (support) as one alternative way that can be done by hypertensive patients to minimize the frequency of recurrence of hypertension, through the regulation and modification of diit in hypertensive patients and the need for counseling about hypertension is carried out continuously by health workers.

Keywords: attitude, frequency of recurrence, hypertension

\section{PENDAHULUAN}

Kekambuhan pada penderita hipertensi sering terjadi selama hidupnya. Kekambuhan tersebut merupakan dampak dari faktor sikap yang tidak dapat dihindari oleh individu, antara lain ketidak adequatan dalam menghadapi stress dan beban kerja yang cukup tinggi. Sering kali penderita hipertensi juga menyalahkan makanan dan lingkungan sekitarnya sebagai penyebab terjadinya hipertensi. Padahal untuk mencegah terjadinya kekambuhan, penderita harus menetapkan beberapa hal seperti beristirahat dengan cukup, mengatur pola diet, berolahraga, tidak mengkonsumsi alkhohol, menghindari stress serta mengatur beban kerja yang dilakukan setiap hari. Kemampuan mengendalikan diri dan bersikap positif, termasuk di antaranya mengendalikan intensitas dan reaktivitas emosi merupakan hal yang penting dalam pencegahan kekambuhan hipertensi dan pengelolaan tekanan darah (Lovallo\& Gerin, 2007). Apabila penderita hipertensi dapat menerapkan sikap yang baik dalam menyikapi penyakit tersebut maka kekambuhan hipertensi dapat dicegah, tetapi pada kenyataannya mereka tidak mengetahui hal-hal tersebut dan cenderung meremehkan.

Prevalensi penyakit hipertensi yang tergolong tinggi, bukan hanya terjadi di negaranegara maju seperti Amerika Utara dan Eropa, namun juga di negara-negara berkembang, termasuk di Indonesia. Berdasarkan data Riskesdas (2018) prevalensi hipertensi di
Indonesia sebesar $25,8 \%$, prevalensi tertinggi terjadi di Bangka Belitung (30,\%) dan yang terendah di Papua $(16,8 \%)$. Sementara itu, data Survei Indikator Kesehatan Nasional (Sirkesnas) tahun 2016 menunjukkan peningkatan prevalensi hipertensi pada penduduk usia 18 tahun ke atas sebesar 32,4\%. Kenyataan yang ada di masyarakat menunjukkan tingginya prevalensi penderita hipertensi, dimana dari data di Posyandu Lansia di Karah meningkat tiap bulannya.

Dari kejadian hipertensi akan berdampak pada kekambuhan apabila penderita tersebut tidak mampu menerapkan sikap yang dapat mencegah kejadian tersebut. Dari kekambuhan yang terjadi, kemungkinan terbesar adalah disebabkan oleh ketidak tepatan sikap diantaranya penderita tidak mematuhi diet yang ditetapkan, mempunyai kebiasaan merokok, mengkonsumsi alkhohol dan kopi, sering mengalami ketegangan dan kecemasan, kurang berolahraga dan sering mendapatkan stress yang berat Jika penderita hipertensi sering mengalami kekambuhan dan bahkan kekambuhan tersebut bersifat lebih berat daripada sebelumnya tentu hal tersebut akan berdampak pada terjadinya penyakit yang lain seperti stroke, gagal jantung, dan gagal ginjal (Smeltzer\& Bare, 2017).

Tindakan yang dapat dilakukan terhadap penderita hipertensi yang mengalami kekambuhan selain terapi farmakologis adalah penderita harus dapat menerapkan sikap atau perilaku yang meliputi selalu mematuhi diit yang 
ditetapkan, menghilangkan kebiasaan merokok dan minum kopi, menghindari stress yang berat, tidak mengkonsumsi alkhohol serta beristirahat dengan cukup. Dengan menerapkan beberapa perilaku atau sikap tersebut diharapkan penderita hipertensi tidak mengalami kekambuhan.

Berdasarkan latar belakang yang telah diuraikan diatas maka peneliti tertarik untuk meneliti "Hubungan Sikap Tentang Hipertensi dengan Frekwensi Kekambuhan pada Penderita Hipertensi di RW 2 Kelurahan Karah Kecamatan Jambangan".

\section{METODE}

Metode dalam penelitian ini adalah deskriptif analitik dengan menggunakan tehnik sampling yaitu accidental sampling sejumlah 24 orang yang menderita hipertensi di RW 06 Kelurahan Karah Kecamatan Jambangan Variabel dalam penelitian ini adalah sikap tentang hipertensi dan frekuensi kekambuhan. Pengumpulan data menggunakan kuesioner. Analisa data yang digunakan uji statististik lambda.

\section{HASIL DAN PEMBAHASAN \\ HASIL}

Tabel 1 Distribusi Frekuensi berdasarkan Karakteristik Penderita Hipertensi di RW 06 Karah Kecamatan Jambangan Surabaya

\begin{tabular}{lcc}
\hline Variabel & $\begin{array}{c}\text { Frekuensi } \\
\text { (f) }\end{array}$ & $\begin{array}{c}\text { Prosentase } \\
(\%)\end{array}$ \\
\hline Jenis Kelamin & & \\
Laki-laki & 14 & 58.30 \\
Perempuan & 10 & 41.7 \\
Usia & & \\
- - 35-45 & 5 & 20.80 \\
- 44-52 & 9 & 37.50 \\
- 53-61 & 6 & 25 \\
- 62-70 & 4 & 16.7 \\
Pendidikan & & \\
terakhir & & \\
SD & 14 & 58.30 \\
SMP & 4 & 16.7 \\
SMA & 5 & 20.80 \\
\hline
\end{tabular}

\begin{tabular}{lcc}
\hline PT & 1 & 4.2 \\
Pekerjaan & & \\
PNS & 1 & 4.2 \\
Swasta & 5 & 20.8 \\
Wiraswasta & 13 & 54.2 \\
Tidak Bekerja & 5 & 20.8 \\
\multicolumn{1}{c}{ Total } & 24 & 100 \\
\hline
\end{tabular}

Sikap Pada Penderita Hipertensi di RW 06 Karah Kecamatan Jambangan Surabaya

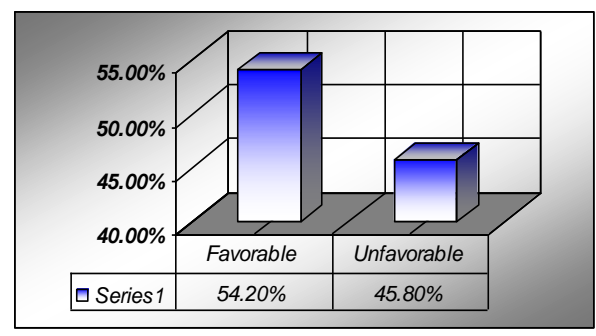

Sumber, Kuesioner, 2018

Gambar 1. Diagram Distribusi Sikap Tentang Pada Penderita Hipertensi di RW 06 Karah Kecamatan Jambangan Surabaya

Pada penelitian ini didapatkan responden yang memiliki sikap Favorable sebanyak 13 orang $(54.20 \%)$ dan Unfavorable sebanyak 11 orang $(45.80 \%)$.

\section{Frekwensi Kekambuhan Pada Penderita Hipertensi di RW 06 Karah Kecamatan Jambangan Surabaya}

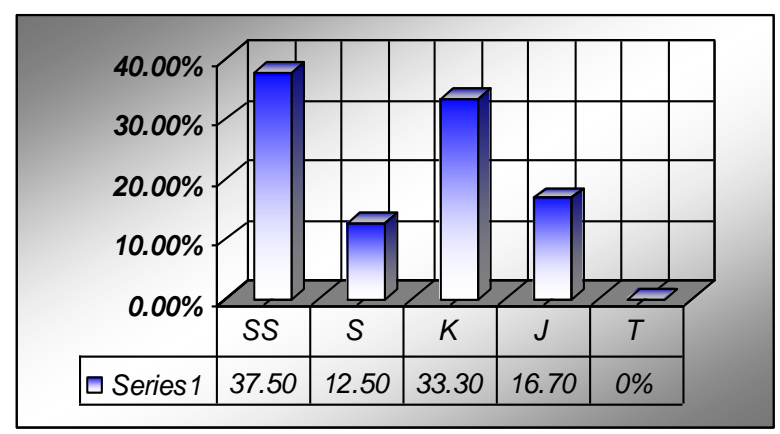

Sumber, Kuesioner, 2018

Gambar 2 Diagram Distribusi Frekwensi Kekambuhan Pada Penderita 
Hipertensi di RW 06 Karah Kecamatan Jambangan Surabaya

\section{PEMBAHASAN}

Sikap Tentang Hipertensi Pada Penderita Hipertensi di RW 06 Karah Kecamatan Jambangan Surabaya.

Berdasarakan gambar 1 diatas dalam penelitian ini didapatkan sebanyak 13 orang $(54.20 \%)$ memiliki sikap favorable dan sebanyak 11 orang $(45.80 \%)$ memiliki sikap unfavorable.

Sikap merupakan reaksi atau respons seseorang yang masih tetutup terhadap stimulus atau objek (Notoadmojo, 2014). Pembentukan sikap ini dipengaruhi oleh beberapa faktor diantaranya adalah pendidikan. Dengan tingginya taraf pendidikan diharapkan akan terbentuk sikap-sikap yang favorable dari diri individu tersebut. Didalam kehidupan sehari-hari sikap memiliki fungsi yang sangat penting, salah satu fungsi sikap tersebut adalah sebagai pertahanan ego dimana sewaktu individu tersebut mengalami hal yang tidak menyenangkan serta akan mengancam egonya atau sewaktu ia mengetahui fakta dan kebenaran yang tidak mengenakkan bagi dirinya maka sikapnya dapat berfungsi sebagai mekanisme pertahanan ego yang akan melindunginya dari kepahitan kenyataan tersebut (Azwar, 2014).

Berdasarkan data umum dari hasil penelitian didapatkan seluruh responden merupakan individu yang pernah mendapatkan pendidikan. Sebagian besar dari mereka $(58.30 \%)$ memiliki tingkat pendidikan SD dan sebagaian kecil lainnya $(4.20 \%)$ memiliki tingkat pendidikan perguruan tinggi. Didalam teori dijelaskan bahwa dengan tingginya taraf pendidikan maka diharapkan akan terbentuk sikap-sikap yang favorable, hal ini tidak sesuai dengan kenyataan yang didapatkan dalam penelitian. Karena dari sebagian besar responden yang memiliki pendidikan SD didapatkan sebagian besar memiliki sikap yang favorable $(54.20 \%)$ sedangakan sebagian kecil lainnya (45.80\%) memiliki sikap yang unfavorable. Kesenjangan ini juga bertolak belakang dengan penelitian Zimmerman (2014) yang menyatakan bahwa pendidikan yang tinggi berkontribusi pada komunikasi yang lebih aktif ( lebih ekspresif dan aktif dalam mengajukan pertanyaan, sehingga jawaban-jawaban tersebut dapat menjadi pedoman dan arahan dalam memberikan perawatan atau melaksanakan hidup sehat serta lebih berpartisipatif dalam kegiatan yang terkait dengan kesehatan seperti senam lansia

Peneliti berpendapat bahwa perbedaan sikap pada penderita hipertensi merupakan hal yang wajar karena banyak sekali faktor-faktor yang mempengaruhi pembentukan sikap, antara lain karena banyaknya sumber informasi yang didapat responden seperti media massa (cetak dan elektronik) serta penyuluhan-penyuluhan tentang hipertensi yang dilakukan di tempat pelayanan kesehatan. Hal ini sesuai dengan penelitian Hahn dan Trumann (2015) yang menunjukkan bahwa pengetahuan dan ketrampilan yang terkait dengan kesehatan dapat dimiliki oleh seseorang dari berbagai program dan kebijakan yang disosialisasikan oleh pemerintah terutama dalam hal ini adalah program promotif dan preventif yang dimiliki oleh puskesmas

\section{Frekwensi Kekambuhan Pada Penderita Hipertensi di RW 06 Karah Kecamatan Jambangan Surabaya.}

Berdasarkan diagram 2 didapatkan responden yang memiliki tingkat kekambuhan sering sekali sebanyak 9 Orang $(37.50 \%)$, sering sebanyak 3 orang $(12.50 \%)$, kadang-kadang sebanyak 8 orang $(33.30 \%)$, jarang sebanyak 4 orang $(16.70 \%)$.

Frekwensi kekambuhan merupakan kejadian berulang dari sebagian penyakit yang telah diderita sebelumnya. Frekwensi kekambuhan pada hipertensi terjadi karena berbagai macam faktor pencetus diantaranya stress fisik dan psikologis, diet yang kurang tepat (tinggi garam), kebiasaan merokok, konsumsi alkohol, dan kuragnya olahraga. Hal tersebut juga tidak jauh berbeda dengan faktor yang mempengaruhi timbulnya hipertensi diantaranya genetik, umur, jenis kelamin, etnis, obesitas, pola asupan diet tinggi garam, merokok dan tipe kepribadian (Pitaloka dan Muhlisin, 2010). 
Berdasarkan data umum distribusi jenis kelamin didapatkan dari 14 orang laiki-laki sebanyak 8 orang $(57.14 \%)$ mengalami frekwensi kekambuhan sering sekali dan dari 10 orang perempuan sebanyak 1 orang $(10 \%)$ mengalami frekuensi kekambuhan sering sekali. Data tersebut tidak sesuai dengan teori yang menyebutkan prevalensi hipertensi pada laki-laki sama dengan perempuan. Hasil lain menunjukkan bahwa sebanyak 5 orang (20.80\%) berusia 35 - 43 tahun, sebanyak 9 orang (37.50\%) berusia 44-52 tahun, sebanyak 6 orang $(25 \%)$ berusia 53-61 tahun, sebanyak 4 orang $(16.70 \%)$ berusia 62-70 tahun. Dari prosentase tersebut dapat diartikan para responden yang mengalami kekambuhan hipertensi lebih banyak terjadi pada rentan usia 35-52 tahun. Hal ini sejalan dengan penelitian Bo Hu dkk (2015) yang menyatakan bahwa pertengahan usia (35-50 tahun) banyak yang terkena hipertensi mengingat faktor pencetus hipertensi serta kekambuhan hipertensi sangat beragam seperti stres fisik dan psikologis, diet yang kurang tepat, kebiasaan merokok, adanya keturunan serta kurangnya waktu untuk berolahraga.

Dari hasil pengamatan peneliti terhadap frekwensi kekambuhan hipertensi, maka peneliti berpendapat peningkatan frekwensi kekambuhan hipertensi tersebut perlu untuk diperhatikan dan menghindari faktor-faktor pencetus kekambuhan hipertensi karena apabila peningkatan frekwensi kekambuhan tersebut terus berlanjut akan berdampak terhadap timbulnya berbagai macam komplikasi.

\section{Hubungan Sikap Tentang Hipertensi Dengan Frekwensi Kekambuhan Pada Penderita Hipertensi di RW 06 Karah Kecamatan Jambangan Surabaya.}

Berdasarkan hasil perhitungan statistik yang dilakukan dengan SPSS 16 menggunakan uji indeks korelasi (uji lambda) didapatkan nilai probabilitas sebesar 0.002 dari jumlah sample 24 orang dengan taraf signifikan $0.05 \%$.

Dari perhitungan di atas ternyata nilai $\mathrm{p}$ (0.002) lebih kecil dari $\alpha$ (0.05) maka Ho ditolak dan Ha diterima. Hal ini terbukti bahwa terdapat hubungan yang signifikan antara Sikap Tentang Hipertensi Dengan Frekwensi Kekambuhan Pada Penderita Hipertensi di RW 06 Karah
Kecamatan Jambangan Surabaya. Selain itu juga didaptkan nilai besarnya korelasi 0.467 (diantara 0.40-0.599) yang menunjukkan bahwa kekuatan korelasinya sedang.

Peran sikap dalam meminimalkan frekwensi kekambuhan sangatlah besar, terbukti dari 13 orang responden yang memilki sikap favorable 1 orang diantaranya mengalami kekambuhan sering sekali (4x dalam sebulan), 1 orang diantaranya mengalami kekambuhan sering (3x dalam sebulan) dan 12 orang diantaranya mengalami kekambuhan yang jarang dan kadang-kadang (1-2x dalam sebulan). Seseorang yang memiliki sikap favorable tetapi mengalami kekambuhan jarang dan kadang kadang kambuh, dimungkinkan karena adanya perhatian dari keluarga untuk memantau keteraturan minum obat antihipertensi, pengetahuan yang terkait dengan penyakit hipertensi, serta beberapa faktor yang lain. Hal tersebut sesuai dengan Notoadmojo (2008) yang menyatakan bahwa ada berbagai pengaruh yang dapat mempengaruhi sikap seseorang diantaranya adalah faktor internal dan faktor eksternal, sesuai pula dengan penelitian Menanga dalam Wardt (2017) yang menyatakan bahwa keteraturan dalam minum obat antihipertensi dan gaya hidup yang sehat berkorelasi positif terhadap frekunsi kekambuhan, sedangkan dalam penelitian Langford dkk dalam Zanchetti (2015) untuk menurunkan kekambuhan hipertensi adalah dengan menurunkan berat badan dan mengurangi konsumsi garam

\section{KESIMPULAN}

1. Pada penelitian ini jumlah responden 24 orang didapatkan responden yang memiliki sikap favorable sebanyak 13 orang $(54.20 \%)$ dan unfavorable sebanyak 11 orang $(45.80 \%)$.

2. Pada penelitian ini jumlah responden 24 orang didapatkan responden yang memiliki tingkat kekambuhan sering sekali sebanyak 9 Orang $(37.50 \%)$, sering sebanyak 3 orang $(12.50 \%)$, kadang-kadang sebanyak 8 orang $(33.30 \%)$, jarang sebanyak 4 orang $(16.70 \%)$.

3. Berdasarkan hasil perhitungan statistik yang dilakukan i dengan bantuan SPSS 16 menggunakan uji (lambda dan fisher's 
exact test) didapatkan nilai probabilitas (p) sebesar (0.000) lebih kecil dari $\alpha(0.05)$ maka Ho ditolak dan Ha diterima yang menunjukan adanya hubungan yang signifikan antara Sikap Tentang Hipertensi Dengan Frekwensi Kekambuhan Pada Penderita Hipertensi di RW 06 Karah Kecamatan Jambangan Surabaya. Selain itu juga didapatkan nilai besarnya korelasi 0.467 yang menunjukkan bahwa kekuatan korelasinya sedang.

\section{DAFTAR PUSTAKA}

Azwar, Saifuddin. 2014. Sikap Manusia Teori dan Pengukurannya, edisi kedua. Yogyakarta: Pustaka Pelajar

Bo $\mathrm{Hu}$, Xiaoyu Liu, Sufeng Yin, Hongmin Fan, Fumin Feng, and Juxiang Yuan. 2015. Effects of Psychological Stress on Hypertension in Middle-Aged Chinese: A Cross-Sectional Study. PLoS;10(6): e0129163.

Hahn, Robert A \& Benedict Truman. 2015. Education Improves Public Health and Promotes Health Equity. Int J Health Serv. 2015; 45(4): 657-678.

Lovallo\& Gerin. 2007. Faktor Resiko Terjadinya Kekambuhan Hipertensi. http://www.smallcrab.com. Tanggal 11 Juli 2018

Muhlisin, Abi dan Ryan Adi Laksono. 2010. Analisis Pengaruh Faktor Stres Terhadap Kekambuhan Penderita Hipertensi Di Puskesmas Bendosari Sukoharjo. Prosiding Seminar Ilmiah Nasional Kesehatan , ISSN: 23382694

Notoadmojo, Soekidjo. 2014. Ilmu Kesehatan Masyarakat Prinsip-prinsip Dasar. Jakarta: PT. Rineka Cipta
Pitaloka, Dyah Ayu. 2010. Faktor-Faktor yang Berhubungan dengan Kejadian Hipertensi Pada Pasien yang Berobat di Poliklinik PuskesamasBangkinang. Jurnal Kesehatan Volume 3 No 2. https://publikasiilmiah.ums.ac.id/handl e/11617/2928?show=full. Diakses tanggal 25 Juli 2018

Suzanne C. Smeltzer, Brenda G. Bare. 2009. Buku Ajar Keperawatan Medikal-Bedah Brunner \& Suddarth. Jakarta: EGC

Riskesdas. 2018. Hipertensi Membunuh Diamdiam, Ketahui Tekanan Darah Anda. http://www.depkes.go.id/article/view/18 051600004/hipertensi-membunuh-diamdiam-ketahui-tekanan-darah-anda.html. Diakses tanggl 2 Januari 2019

Wardt V, van der, Harrison JK, Welsh T, Conroy S, Gladman J. 2017. Withdrawal of Antihypertensive Medication: a Systematic Review. J Hypertens. 2017 Sep;35(9):1742-1749.

Zanchetti, Alberto.. 2015. Factors influencing blood pressure levels. Journal of Hypertension: August 2015 - Volume 33 - Issue 8 - p 1497-1498.

Zimmerman, Emily B, Steven H Woolf dan Amber Haley. 2014. Population Health: Behavioral and Social Science Insight (Understanding the Relationship Education and Health).https://www.ahrq.gov.id. Diakses tangal 2 Januari 2019 